A RCHIWA, BIBLIOTEKI

I MUZEA KOŚCIELNE 109 (2018)

https://doi.org/10.31743/abmk.2018.109.09

MARTA GUDOWSKA* - LUBLIN

\title{
CODZIENNOŚĆ NAJMLODSZYCH DZIECI W POLSKIM MALARSTWIE RELIGIJNYM 1400-1550
}

Temat dziecka i dzieciństwa na przestrzeni wieków pozostaje nadal żywotny w dyskusjach oraz publikacjach wielu badaczy, szczególnie europejskich ${ }^{1}$, reprezentujących różne dziedziny. Wpływ na taki stan rzeczy miała zapewne rozprawa francuskiego historyka Philippe'a Arièsa L'Enfant et la vie familiale sous l'Ancien Régime, która przyjęta entuzjastycznie, do dziś stanowi impuls do krytycznego spojrzenia na prezentowane zagadnienie. Wciąż jednak niewiele jest prac na gruncie polskiej nauki, szczególnie w dziedzinie historii czy historii sztuki, dotykających problemu dziecka i dzieciństwa, zwłaszcza w czasach dawnych. Bogactwo malarstwa polskiego ${ }^{2}$, głównie małopolskiego o charakterze religijnym pozwoliło wyodrębnić tak szczegółowe zagadnienie, jakim jest codzienność najmłodszych dzieci - cały entourage związany głównie z pierwszym okresem dzieciństwa - od momentu narodzin ${ }^{3}$ (ostatnia, trzecia część tekstu „zabawki” łączy w sobie elementy świata noworodków i niemowląt oraz małych dzieci).

* Marta Gudowska - mgr historii sztuki; doktorantka w Instytucie Historii Sztuki KUL; e-mail: fioletowamrowa@gmail.com

${ }^{1}$ Z najnowszych publikacji należy wymienić: N. Orme, Medieval Children, New Haven 2001; E. Baumgarten, Mothers and Children. Jewish Famili Life in Medieval Europe, Princeton 2004; A. Classen, Childhood in the Middle Ages and the Renaissance. The Results of a Paradigm Shift in the History od Menrality, Berlin-New York 2005; The Christ Child in Medieval Culture: Alpha es et O!, red. M. Dzon, T.M. Kenney, Toronto-Buffalo-London 2012; J.A. Mitchell: Becoming Human: The Matter of the Medieval Child, Minneapolis 2014.

${ }^{2}$ Rdzeń materiału źródłowego dla poruszanego zagadnienia stanowi polskie malarstwo 1400 1550. Wyznaczony w temacie zakres czasowy pozwala spojrzeć na sztukę schyłku średniowiecza i początków nowożytności. Pod uwagę wzięte zostały przykłady malarstwa tablicowego, ściennego i miniatorstwa, których proweniencja, bądź miejsce przeznaczenia mieści się w terytorium ówczesnego Królestwa Polskiego. Przykłady z ziem sąsiadujących z nim, pojawią się dla ukazania powszechności, czy też typowości pewnych elementów dotyczących referowanego zagadnienia.

${ }^{3}$ Już w starożytności podejmowano dyskusje nad etapami życia ludzkiego. Warron, Cyceron, Horacy i Seneka proponowali podział na: puer, adulescens, iuvenis, senex; Hezjod i Pindar natomiast na trzy części. Solona i Arystoteles uważali, że życie człowieka składa się z siedmioletnich 


\section{Powijaki. Kołyski. Akcesoria}

Lista rzeczy potrzebnych do sprawowania opieki nad noworodkiem tuż po jego przyjściu na świat, przez ostatnie sześć wieków w zasadzie nie uległa zmianie. Koniecznymi, tak dzisiaj, jak i w przeszłości były powijaki (czyli dzisiejszy becik), kołyska i sysułka (pierwowzór smoczka). Sredniowieczni rodzice znali także sprzęty, które miały wspomóc rozwój ich dzieci. Zaliczyć do nich można sustentaculum (chodzik) oraz nocnik ${ }^{4}$.

Powijaki stosowano od starożytności, a być może jeszcze wcześniej. Dokładna instrukcję owijania noworodka podał Soranus, który zalecał zaraz po pierwszej kąpieli owinięcie wszystkich członków osobno, opaskami o szerokości do czterech palców. Jan Lachs, komentujący Soranusa, zwrócił uwagę, że współcześni Lapończycy (XX w.) również stosowali tę metodę . Powijaki cieszyły się popularnością, ponieważ zabezpieczały dzieci przez włożeniem sobie do ust drobnych przedmiotów. Zbyt ciasne krępowanie ciała powodowało jednak wady rozwojowe, szczególnie bioder i nóg ${ }^{6}$. W ikonografii można spotkać dwa rodzaje powijaków: pozostawiające główkę dziecka odkrytą lub zakrytą. Sposób ich wiązania prawdopodobnie na trójkąt - co sugeruje nieosłonięta szyja niemowlęcia, sprawia wrażenie luźnego otulenia, pomimo ułożenia rączek wzdłuż tułowia. Takie powijaki składały się przeważnie z jednego rodzaju tkaniny - białego płótna. Zaobserwować je można na kwaterze Narodziny Marii z Poliptyku olkuskiego autorstwa Jana Wielkiego i Stanisława Starego (ok. 1485 r.), obrazie Rodzina Marii Panny z Otpin Mistrza Rodziny Marii (ok. 1510-1515) oraz na obrazie Wielka Rodzina Marii z Probołowic (1510-1515). W scenie rzezi niewiniątek z Ottarza Jerozolimskiego (1495-1500) widać niemowlę otulone dwiema warstwami dzianiny, prezentujące również pierwszy typ powijaków. Wśród drugiego rodzaju powijaków - zakrywających główkę - występowały też jednoczęściowe, jak kolejny przykład z Oltarza Jerozolimskiego, tym razem ze sceny najazdu żołnierzy Heroda na

okresów, wynikających z naturalnego rytmu. Kwestię etapów życia skomplikowali nieco myśliciele chrześcijańscy i ojcowie Kościoła. Tutaj często pojawiała się liczba siedem (św. Ambroży z Mediolanu), którą chętnie powtarzali uczeni średniowieczni. Od IV do XII w. utrzymywał się u filozofów podział dzieciństwa na dwie części: infantia oraz puertia, trwające po siedem lat (św. Ambroży z Mediolanu, św. Izydor z Sewilli, św. Beda Czcigodny, Bartłomiej Anglik). Podobnie kwestie te ujmowały obserwacje starożytnych i średniowiecznych medyków - zgodnie wyznaczano koniec dzieciństwa na 14. rok życia, początkowo dzieląc je na cztery (pojawienie się pierwszych zębów - ok. 12. miesiąc, koniec karmienia piersią - ok. 2. rok życia, pojawienie się stałych zębów/ początek edukacji - 6/7 rok życia, lata chłopięce do 14. roku życia), potem na trzy części (infantia - do końca karmienia piersią, do 7. roku życia, puertia - do 14. roku życia). Szerzej na ten temat: M. Delimata, Dziecko w Polsce średniowiecznej, Poznań 2004, s. 29-35; D. Żołądź-Strzelczyk, Rozumienie dzieciństwa, w: Dziecko w rodzinie i spoleczeństwie. Starożytność-średniowiecze, t. 1, red. J. Jundziłł, D. Żołądź-Strzelczyk, Bydgoszcz 2011, s. 9-24; A. Teterczyn-Puzio, Dziecko i dzieciństwo w świetle wybranych źródet narracyjnych (do XIV w.), „Studia Gdańskie”, 28 (2011) s. 257276.

${ }^{4}$ Wymienione zostały tylko te przedmioty, które udało odnaleźć się w ikonografii.

${ }^{5}$ Ginekologia Soranusa z Efezu, tłum. J. Lachs, „Roczniki Towarzystwa Przyjaciół Nauk Poznańskiego", 28 (1902) s. 33.

${ }^{6}$ J. Tyszkiewicz, Ludzie i przyroda w Polsce średniowiecznej, Warszawa 1983, s. 255. 
miasto. W większości przypadków drugi typ składał się jednak z dwóch rodzajów materiałów, z czego wierzchni był bogatszy, zdobiony. Takie powijaki prezentują obrazy Wielka Święta Rodzina z Szydłowca (ok. 1510-1515), Rodzina Marii ze Szczyrzyca (XVI w.) oraz Rodzina Marii (XVI w.) o niezidentyfikowanej proweniencji, przechowywana obecnie w Muzeum Narodowym w Krakowie. Ciekawe jest, że dwa pierwsze ujęcia powijaków wymienione w drugim typie są niemal identyczne: biały „czepek” i materiał zewnętrzny w czarno-białe pasy tworzący róg. Powijaki nie służyły dziecku zbyt długo. Próbujące chwytać czy podnosić się, niemowlę potrzebowało ubrania zapewniającego mu swobodę. Zródła ikonograficzne wskazują na stosowanie luźnych białych koszulek. Najwcześniejszy przykład pochodzi z obrazu Św. Anna Samotrzeć ze Strzegomia (ok. 1400 r.), na którym widać Dzieciątko Jezus ubrane w lekko prześwitującą koszulkę z krótkim rękawem, sięgającą do połowy uda, z rozcięciami po bokach. Podobny fason zaobserwować można na fragmencie bordiury na piątej stronie Elblaskiej księgi łąkowej (1421 r.). Nieco inny krój - bo i dla małego dziecka a nie niemowlaka - widać na wspominanej już kwaterze Rzeź niewiniątek z Ottarza Jerozolimskiego. Tutaj koszula jest znacznie dłuższa, z długim rękawem, oraz rozcięciem z tyłu. Niewykluczone jednak, że malarz przedstawił tu przykład bielizny nocnej. Widoczne rozcięcie wzdłuż karku prawdopodobnie stwarzało możliwość regulowania otworu na głowę poprzez ściągnięcie sznurkiem, czy spięcie. Warto zauważyć natomiast, że wszystkie prezentowane koszulki nie mają żadnych ozdób, nie wyróżnia ich nic szczególnego. Różnice wypływające z długości koszuli, czy rękawów mogły wynikać po prostu z próby dostosowania ubioru do pory roku tak samo z materiałem: cieńszym lub grubszym.

Kolejnym przedmiotem niezbędnym od pierwszych dni życia dziecka była kołyska. Służyła nie tylko jako miejsce spania, ale również chroniła przed urazami i uduszeniem ${ }^{7}$. Jan Drabina rozróżnia dwa typy kołysek: starszy - wiszący i nowszy - na biegunach. Wspomina też o ich zdobieniach malowidłami, bądź rzeźbami, uzależniając to od zamożności, albo zdolności manualnych ojca ${ }^{8}$. Wiszące kolebki chroniły dziecko przed pchłami ${ }^{9}$ oraz zwierzętami mogącymi wchodzić do domu. W Legendzie św. Jadwigi zachował się opis dotyczący przywrócenia do życia siedmiotygodniowej Pietruchy, którą opiekunka pozostawiła samą w kołysce. Do chałupy wpadł wieprz i przewrócił kolebkę, a dziewczynka nieomal udusiła się pod powijakami i poduszkami ${ }^{10}$. Kołyski na biegunach powszechne były w miastach ${ }^{11}$. Były też mniej bezpieczne, szczególnie dla ruchliwych niemowląt, przez możliwość przewrócenia. Dbano również o odpowiednie

${ }^{7}$ B. Wojciechowska, Dziecko w kulturze Polski średniowiecznej, „Kieleckie Studia Historyczne", 9 (1991) s. 6.

${ }^{8}$ J. Drabina, Życie codzienne w miastach ślaskich XIV i XV w., Wrocław 1998, s. 18.

${ }^{9} \mathrm{~S}$. Lewiński, Niektóre zagadnienia dotyczace higieny we wczesnośredniowiecznych osiedlach na terenie Polski, „Acta Universitatis Nicolai Copernici. Nauki Humanistyczno-Społeczne. Archeologia IV", 1974, z. 60, s. 139-149.

${ }^{10}$ Legenda świętej Jadwigi, tłum. A. Jochelson, Wrocław 1993, s. 113.

${ }^{11}$ Delimata, Dziecko, s. 86. 
wyścielenie kołyski i poduszki ${ }^{12}$. Materiał ikonograficzny omawianego okresu prezentuje jedynie drugi typ kołyski - do ustawienia na podłodze. Można sądzić, iż powodem tej sytuacji jest fakt używania takiego sprzętu przez osoby zamożniejsze. Zebrane ilustracje pokazują dwie formy bujanej kolebki. Pierwsze trzy: z kwatery Narodziny Marii z Poliptyku Olkuskiego, inicjału „G(audemus)” z 253 karty Mszału Jasnogórskiego (1506-1507) i miniatury Narodziny Marii z 23 karty Pontyfikatu Erazma Ciołka (1510-1512) przypominają łóżka z płozami przymocowanymi do szerokości skrzyni. Wyróżniają się także ozdobami w postaci sterczyn umieszczonych na rogach. Zupełnie inna konstrukcyjnie od powyższych jest ostatnia kołyska, ukazana na głównej tablicy tryptyku Rodzina Marii ze Stobiecka Miejskiego (1519 r.). Kształtem przypomina połowę walca i ustawiona jest na wysokiej skrzyni (pierwsza z prezentowanych stoi na niskim podeście). Pierwsze trzy pokazują tradycyjnie posłane łóżko: kołdra, wzorzysta narzuta, duża poduszka. Ostatni przypadek jest o tyle ciekawy, że prezentuje dziecko leżące na płaskiej poduszce, przykryte kołdrą i dodatkowo zasznurowane na wierzchu.

W okresie średniowiecza, do uspokojenia dziecka wykorzystywano nie tylko bujanie w kołysce. Alternatywą była sysułka czyli kawałek materiału, najczęściej płótna, zwinięty w kulkę z wypustką do trzymania. Środek wypełniano makiem albo miodem. Prawdopodobnie właściwości maku, a raczej opium, które jest z niego otrzymywane, znane były już za czasów Homera. Wspomina on w $O d y-$ sei o „eliksirze zwanym nepenthe, który pozwalał Helenie Trojańskiej zapomnieć o wszelkich troskach; wielu uczonych uważa, że nepenthe to napój sporządzony na bazie opium"13. Papaver somniferum, czyli mak lekarski zawiera alkaloidy działające uspokajająco i przeciwbólowo, stąd ssanie sysułki dawało pożądane efekty i uspokajało dziecko. W malarstwie prototyp dzisiejszego smoczka pojawia się na obrazach z Matką Bożą i Dzieciątkiem Jezus, bądź św. Anną Samotrzeć. Znacznie popularniejszy był w sztuce europejskiej, aniżeli w polskiej. Do rodzimych przykładów można zaliczyć obraz Madonna ze szczygłem z Dębna koło Kalisza (ok. 1450 r.), na którym widać taką samą sysułkę jak na malowidle Św. Anna Samotrzeć ze Strzegomia (ok. 1400 r.).

Po okresie noworodkowym (aktualnie to miesiąc po urodzeniu ${ }^{14}$ ) następuje okres niemowlęcy. Dziecko od tego momentu staje się coraz bardziej ruchliwe, odkrywa istnienie swoich rąk i nóg, a co za tym idzie i ich możliwości. Około dziewiątego miesiąca, niemowlak próbuje podnosić się i stawiać pierwsze kroki. Dzisiaj pomaga mu w tym chodzik (coraz częściej potępiany przez ortopedów), natomiast 500 lat temu było to sustentaculum ${ }^{15}$. Ta drewniana konstrukcja jeżdżąca po podłożu na trzech kołach $^{16}$, pełniła rolę podpory dla stawiającego pierwsze kroki

${ }^{12}$ Takie wskazówki dawał już Soranus. Zob. Ginekologia Soranusa z Efezu, s. 77-78.

${ }^{13}$ A. Stewart, Zbrodnie roślin. Chwast, który zabit matkę Abrahama Lincolna i inne botaniczne okropieństwa, thum. D. Wójtowicz, Warszawa 2012, s. 108.

${ }^{14}$ Nasze dziecko, red. R. Rokicka-Milewska, Warszawa 2007, s. 166.

${ }^{15}$ W. Dobrowolski, Jesus with a sustentaculum, w: Ars auro prior. Studia Ioanni Białostocki sexagenario dicta, red. J.A. Chrościcki i in., Warszawa 1981, s. 201-208.

${ }^{16}$ Europejskie przykłady prezentują konstrukcję czterokołową: Histoire ancienne jusqu' à César, k. 031v, 3. ćw. XV w., Francja, MS Douce 353, Oxford, Bodleian Library; Livre d'heures de la 
dziecka. Ilustruje to w rodzimej sztuce fragment malowidła z krużganków kościoła augustianów w Krakowie, przedstawiający niewiniątka w raju (pocz. XVI w.). Identyczną konstrukcję widać na rewersie lewego wewnętrznego skrzydła dolnej kwatery Poliptyku Zwiastowania: Pierwsze kroki Jezusa z Wrocławia (ok. 1480 r.) oraz na fragmencie bordiury 5 strony Elblaskiej księgi łąkowej (1421 r.). Występowanie tożsamych przedstawień sustentaculum $\mathrm{w}$ różnych regionach może wskazywać na powszechne używanie na tym terenie tej przydatnej w rozwoju dziecka konstrukcji, albo na funkcjonowanie pewnego schematu wśród działających tu wówczas malarzy.

Ostatnim z wymienionych elementów dziecięcych jest nocnik. Najczęściej wykonany był z gliny, szkła, miedzi, cyny lub porcelany ${ }^{17}$. Ilustracją potwierdzającą używanie nocnika w omawianym czasie jest obraz Św. Mikołaj obdarowujący trzy ubogie dziewczęta z Żelichowa (1510-1520). Za taką identyfikacją powyższego przedmiotu przemawia miejsce jego ulokowania na obrazie: na skrzyni stojącej przed łóżkiem.

\section{Karmienie niemowlęcia}

W sprawie żywienia noworodków i niemowląt, średniowieczni medycy powielali poglądy swoich starożytnych poprzedników: Soranusa, czy Galena ${ }^{18}$. Przykładowo, XI-wieczna włoska medyczka Trotula z Salerno, w swojej pracy poświęconej chorobom kobiet, wspomniała o karmieniu niemowląt, opierając swoje zalecenia na pismach Soranusa. Twierdził on, że noworodek nie powinien dostawać żadnego pokarmu przez pierwsze dwa dni swojego życia, a w przypadku, gdyby było to konieczne, zalecał miód rozcieńczony wodą. Postulował karmienie piersią przez matkę, chociaż nie przez pierwsze 20 dni. Na ten czas należało poszukać noworodkowi mamki, a kiedy znalezienie jej nie było możliwe, należało trzy doby karmić dziecko mlekiem kozim z miodem, a następnie przystawić do piersi ${ }^{19}$. Średniowieczni lekarze zalecali noworodkom pierwszy pokarm po około dobie od przyjścia na świat, w postaci miodu z mlekiem kozim, bądź oleju z migdałów, masła, cukru rozpuszczonego w wodzie lub wina. Składniki te miały pomóc dziecku wydalić smółkę ${ }^{20}$. Także chrześcijańscy myśliciele, podobnie jak Soranus, popierali karmienie piersią przez matkę. Cezary z Arles dopuszczał za-

famille Ango (Livre des enfants), k. 26 bis, 1500, Rouen, NAL 392, Paris, Bibliothèque nationale de France; Hours of Catherine of Cleves, k. 149, ok. 1440, Utrecht, MS M.917, New York, The Morgan Library \& Museum.

${ }^{17}$ D. Żołądź-Strzelczyk, K. Kabacińska-Łuczak, Codzienność dziecięca opisana stowem i obrazem. Życie dziecka na ziemiach polskich od XVI do XVIII wieku, Warszawa 2012, s. 118.

${ }_{18}$ S. Silska, Ewolucja poglądów na żywienie niemowląt w XIX i XX wieku, Poznań 2013, s. 27, mps. Praca doktorska napisana pod kierunkiem prof. dr hab. med. Mariana Krawczyńskiego w Uniwersytecie Medycznym im. Karola Marcinkowskiego w Poznaniu. http://www.wbc.poznan. pl/Content/304349/index.pdf (dostęp: 28.10.2014).

${ }^{19}$ Ginekologia Soranusa z Efezu, s. 27.

${ }^{20}$ Silska, Ewolucja poglądów na żywienie niemowląt, s. 29. 
stąpienie jej mamką ${ }^{21}$, natomiast już św. Jan Chryzostom zupełnie to potępiał ${ }^{22}$. Przeciwny mamkom był też autor Rozmyślania przemyskiego. Za wzór kobietom stawiał św. Annę, która sama wykarmiła Maryję ${ }^{23}$. Dobór mamki stanowił bardzo istotny problem, ponieważ wierzono, iż cechy charakteru wyssane były z matczynym mlekiem. Mikołaj Rej pisał:

(...) panie matki, a zwłaszcza te które są przyrodzenia dobrego, bardzo by dobrze, aby samy dziatki swe i karmily i wychowywały (...) [szukać mamki] nie melankolicznej, nie frasowanej, ale co by była przyrodzenia dobrego, obyczajów uczciwych, która aby wnet obaczała, ku czemu by się przyrodzenie dzieciątka onego ściągało ${ }^{24}$.

W średniowieczu dzieci były karmione najprawdopodobniej 2-3 razy w ciągu dnia w przypadku niższych warstw społecznych, ze względu na nieobecność matki pracującej poza domem, bądź też na żądanie w zamożniejszych kręgach ${ }^{25}$. Już wtedy zauważano związek między karmieniem noworodka mlekiem matki, a jego odpornością, co ważne było szczególnie w pierwszych miesiącach życia, ze względu na wysoką umieralność dzieci ${ }^{26}$. O wielkim znaczeniu naturalnego żywienia świadczy fakt, że nawet królowej zalecano karmienie dziecka osobiście $^{27}$. Obecność tego motywu w kronikach, hagiografii a nawet $\mathrm{w}$ pieśniach religijnych ${ }^{28}$ stwarza wrażenie, że już średniowieczne społeczeństwo zdawało sobie sprawę z więzi biologicznych i duchowych łączących matkę z jej dzieckiem, które pogłębiało karmienie piersią. Ponadto sztuczne żywienie łączyło się z ryzykiem śmierci niemowlęcia (ok. 90-100\%), stąd też obserwuje się taki nacisk na karmienie mlekiem matki ${ }^{29}$.

Karmienie piersią rekomendowane było w średniowieczu przez pierwsze dwa lata życia. Sytuacja na chwilę przed karmieniem zilustrowana została na kwaterze Narodziny Marii z Poliptyku olkuskiego autorstwa Jana Wielkiego i Stanisława Starego (ok. 1485 r.). Św. Anna rozchyla dłonią koszulę nocną w obrębie klatki piersiowej, aby przystawić nowonarodzoną Maryję do piersi. Sam moment karmienia piersią stanowi fragment obrazu Rodzina Marii z Racławic Olkuskich (ok. 421.

${ }^{21}$ Cezary z Arles, O moralności, w: A. Bober, Antologia patrystyczna, Kraków 1965, s. 420 -

${ }^{22}$ Jan Chryzostom, Homilie i kazania wybrane, thum. W. Kania, t. 8, Warszawa 1971, s. 63.

${ }^{23}$ „Anna nie tako jako jinne panny czynią jiże szukają jinnych obcych mam, ale swe dzieciątko swymi pirsiami karmiła". (Cyt. za: Wojciechowska, Dziecko w kulturze Polski średniowiecznej, s. 7; rękopis: http://polona.pl/item/257324/1/ (dostęp: 29.10.2014); transkrypcja: http://www.ijp-pan.krakow.pl/images/publikacje_elektroniczne/korpus_tekstow_staropolskich/Rozm.pdf (dostęp: 29.10.2015).

${ }^{24}$ M. Rej, Żywot człowieka poczciwego, red. J. Krzyżanowski, Wrocław 1956, s. 32.

${ }^{25}$ Silska, Ewolucja poglądów na żywienie niemowląt, s. 27.

${ }^{26}$ J. Tyszkiewicz, Ludzie i przyroda w Polsce średniowiecznej, Warszawa 1983, s. 171.

${ }^{27}$ A. Danysz, O wychowaniu królewicza traktat humanistyczno-pedagogiczny z roku 1502, „Prace monograficzne z dziejów wychowania i szkolnictwa w Polsce”, Nr 3: Studia z dziejów wychowania $w$ Polsce, Kraków 1921, s. 13. http://www.kpbc.ukw.edu.pl/dlibra/plain-content?id=1080 (dostęp: 29.10.2014).

${ }^{28}$ Wojciechowska, Dziecko w kulturze, s. 7.

${ }^{29}$ Silska, Ewolucja poglądów na żywienie niemowląt, s. 29. 
1530-1540). Kobieta siedzi prawdopodobnie na poduszce, bądź niskim stołku. Lewą ręką obejmuje nagie dziecko, podtrzymując je kolanem. Prawą podaje mu pierś, którą dziecko próbuje chwycić rączką. Malec nie leży bezpośrednio na sukni matki, ale na białej pieluszce. Malarz przedstawił kobietę w swobodnej pozie. Naturalności przedstawionej sytuacji dodaje też fakt, że kobieta przedstawiona jest w towarzystwie oraz, że nie kryje się z wykonywaną czynnością - wręcz przeciwnie - zwraca głowę w stronę głównej sceny, co sugeruje, że bierze w niej czynny udział. Rozszerzanie diety dziecka Soranus zalecał wraz z początkiem ząbkowania, czyli według niego około szóstego miesiąca ${ }^{30}$. Jan Tyszkiewicz powołując się na Miracula Prandothe pisze, że karmiono dzieci rozmoczonym białym chlebem, lub bułką pszenną już od drugiego miesiąca życia (a nawet wcześniej, w przypadku problemów z laktacją matki) ${ }^{31}$. Aleksander Brückner natomiast twierdzi, że najmłodszym członkom rodziny podawano papiny rozgotowanej mąki jęczmien$n^{j 32}$. Antonina Jelicz pisze, że:

(...) pożywienie dziecka powinno być proste i niewymyślne, złożone z trzech, czterech potraw, nieostrych i niezbyt ciężko strawnych, i tylko jednego gatunku lekkiego wina. Wskazane są także potrawy pospolite, czasem pewne przegłodzenie się dla zdobycia większej odporności. ${ }^{33}$

- wprawdzie autorka nie wspomina o wieku dziecka, dla którego zalecano taką dietę, ale $\mathrm{z}$ dalszego fragmentu dotyczącego żywienia młodzieży wynika, że powyższy cytat dotyczy również małych dzieci. Przedstawieniem związanym z karmieniem dziecka jest fresk Adoracja Dzieciątka Jezus z kościoła Serca Pana Jezusa w Pogorzeli (2. ćw. XV w.). Po prawej stronie sceny św. Józef na prowizorycznej kuchence zbudowanej z pali, gotuje posiłek dla nowonarodzonego Jezusa. Przedstawienia, w których Józef odpowiedzialny jest za strawę rozpowszechnione były w średniowieczu, szczególnie na terenach Niemiec i Czech, skąd przywędrowały do Polski. Do popularności tej sceny przyczyniły się oprócz tradycji malarskiej także sztuki bożonarodzeniowe oraz śląskie pieśni. Dzięki nim św. Józefa postrzegano jako realnego opiekuna Dzieciątka i Jego Matki ${ }^{34}$.

\section{Zabawki}

Już Arystoteles dostrzegał korzystny wpływ zabawy na dzieci. Jego zdanie podzielali także średniowieczni myśliciele: Wincenty z Beauvais i Idzi Rzymia$\operatorname{nin}^{35}$. Średniowieczne zabawki z terenów Polski znamy dziś głównie dzięki wykopaliskom archeologicznym. Wyróżnić tutaj można ,grzechotki, figurki zwierząt i ludzi, miniaturowe przedmioty codziennego użytku oraz narzędzia pracy

${ }^{30}$ Ginekologia Soranusa z Efezu, s. 27.

${ }^{31}$ Tyszkiewicz, Ludzie i przyroda, s. 257.

${ }^{32}$ A. Brückner, Dzieje kultury polskiej, t. 1: Od czasów prehistorycznych do r. 1506, Kraków 1930, s. 486.

${ }^{33}$ A. Jelicz, Życie codzienne w średniowiecznym Krakowie (wiek XII-XV), Warszawa 1966, s. 155.

${ }^{34}$ Z. Kliś, Temat Bożego Narodzenia w polskiej sztuce średniowiecznej, Kraków 1994, s. 109116.

${ }^{35}$ Delimata, Dziecko, s. 95. 
dorosłych, zminiaturyzowane militaria, bączki, instrumenty muzyczne, łyżwy oraz sanki" ${ }^{36}$. W ikonografii omawianego okresu zachowało się ich stosunkowo niewiele, w porównaniu do dzieł powstałych nawet jeden, czy dwa wieki później.

Pierwszą zabawką, jaka kojarzy się dziś z najmłodszymi jest grzechotka. Legenda mówi, że jej twórcą był Archytas z Tarentu ${ }^{37}$. Początkowo oprócz skupiania uwagi dziecka, jej dźwięk wiązano także z funkcją magicznąą, miał odstraszać demony i przeciwdziałać urokom. Grzechotki wykonywano ze skorup zwierząt, orzechów, czy gliny (okrągłe, bądź w formie jakiejś figurki). Dziś wiedzy na ten temat dostarczają wykopaliska archeologiczne, np. znaleziona w Bytomiu Odrzańskim figurka konia (XIV-XV w.) ${ }^{39}$. Innymi zabawkami odnalezionymi przez archeologów na ziemiach polskich, datowanymi na XV-XVI w. są gliniane albo drewniane figurki koni, bądź psów, łódki robione z kory, zminiaturyzowane kusze dziecięce, drewniane miecze, czy małe naczynia ${ }^{40}$. Poświadczenie wykonywania (nawet przez dzieci) glinianych figurek zwierząt znaleźć można w Rozmyślaniu przemyskim:

(Jezus) wyszedszy jednego dnia / z Nazaret z inymi dziećmi 〈przyszedł〉 / ku glinie, gdy była niedawno kopana / tako ony dzieci podług obyczaja / dziecinnego siadszy poczną igrać. Jesus $\langle. .$.$\rangle / uczyniwszy siedem ptaków malutkich$ / i postawił je na słuńcu przed sobą, aby / uschnęli i kazał swem towarzyszom, / aby uczynili takież ${ }^{41}$.

Większość wymienionych zabawek wydawać by się mogło, że jest dedykowana chłopcom gdyż dziewczynki powinny bawić się lalkami. Prawdopodobnie tak też było w Polsce XV i XVI w. Dla porównania można wspomnieć, iż w XV-wiecznych Niemczech produkcją lalek zajmowali się specjalni rzemieślnicy ${ }^{42}$.

Próżno w omawianym polskim malarstwie szukać obrazu na miarę Zabaw dziecięcych Pietera Breugla ${ }^{43}$. Zabawki nie stanowią też głównego tematu malowideł, są jednak w nich ,poukrywane”. Wyłaniają się z dekoracji marginesowej ksiąg. Tak jest w przypadku bordiury 29 karty Graduału Jana Olbrachta (1501 r.). Pomiędzy jeleniem, a walczącymi czeladnikami, wśród wijącej się wyimagino-

${ }^{36}$ Tamże.

${ }^{37}$ Archytas z Tarentu (428-347 p.n.e.) - grecki filozof, matematyk, polityk, przedstawiciel szkoły pitagorejskiej. Według legendy, kiedy dyskutował ze swoim przyjacielem Platonem, gromadka jego dzieci domagając się uwagi, przeszkadzała mu w dysputach. Aby ich czymś zająć, skonstruował z suchego drewna grzechotkę. http://www.muzeumzabawek.eu/mziz/index.php?option=com content\&task=view\&id=304 (dostęp: 01.10.2015).

${ }^{38}$ T. Borkowski, Gry i zabawy w średniowiecznym mieście na Ślasku. Ślady materialne, w: Kultura średniowiecznego Śląska i Czech, red. K. Wachowski, Wrocław 1995, s. 104.

${ }^{39}$ Tamże.

${ }^{40}$ M. Marcinkowski, Zabawki dzieci elblaskich. Prezentacja zbioru z badań wykopaliskowych, w: Dawne i współczesne zabawki dziecięce, red. D. Żołądź-Strzelczyk, K. Kabacińska, Poznań 2010, s. 55-67.

${ }^{41}$ Rozmyślanie przemyskie. http://www.ijp-pan.krakow.pl/images/publikacje_elektroniczne/ korpus_tekstow_staropolskich/Rozm.pdf(dostęp: 01.10.2016).

${ }^{42}$ Delimata, Dziecko, s. 98.

${ }^{43}$ P. Breugl, Zabawy dziecięce, 1560, olej na desce, $118 \times 161$ [cm], Kunsthistorisches Museum Wien. 
wanej roślinności, widać nagiego chłopca o blond włosach. W uniesionej prawej ręce trzyma on zabawkę ze zwisającymi sznurkami, kształtem przypominającą bat. Lewą natomiast przytrzymuje za lejce konia. Wykonany jest on z drewna, składa się z podobizny końskiej głowy i zakrzywionego pałąka, który udaje tułów zwierzęcia. Miniatura Warsztat szewski na 287. karcie Kodeksu Baltazara Behe$m a$ (ok. 1505) wprowadza widza do rozległego pomieszczania. Na środku pola obrazowego, ukazującego po prawej stronie pracujących rzemieślników, namalowana została żona mistrza. Za jej suknią ukrył się mały, zupełnie nagi chłopczyk, o prostych, rudobrązowych włosach. Prawą ręką opiera się o matkę, lewą sięga w stronę leżącego przed nim brązowego przedmiotu. Sądząc po kształcie oraz kolorze, można przypuszczać, że jest to drewniany bạk ${ }^{44}$. Bąk widoczny jest też na tryptyku Rodzina Marii ze Stobiecka Miejskiego (1519 r.). Tutaj przyjmuje on jednak inną formę. Chłopiec (nieco starszy niż jego poprzednik) na uniesionej prawej ręce, na otwartej dłoni kręci bączka złożonego z prostego patyka oraz nałożonego na niego okrągłego kawałka w formie tarczy. Taki bąk uruchamiany był prawdopodobnie sznurkiem. Inną zabawkę odnaleźć można na wspominanym już tryptyku Rodzina Marii z Racławic Olkuskich (ok. 1530-1540). Poniżej głównej sceny ze św. Anną, Maryją i małym Jezusem siedzącymi na ławie, dokładnie na środku, siedzi nagie dziecko, odwrócone do widza prawą stroną. Główkę ma odchyloną do tyłu, wodząc wzrokiem za podrzuconą właśnie złotą piłeczką.

Zaprezentowane przykłady, należące głównie do malarstwa religijnego unaoczniają, że motywy związane z wczesnym dzieciństwem, dotyczące codziennego funkcjonowania noworodka, niemowlęcia, czy małego dziecka stanowią najczęściej tło scen o odmiennej tematyce. Malarze dążyli do aktualizacji scen religijnych, wprowadzając wiele detali zaczerpniętych z codziennego życia współczesnym im mieszkańców wsi i miast. Dlatego spotykane są różnorodne formy stosowanych powijaków czy dwa warianty kołysek. Może to świadczyć o wielości stosowanych wówczas rozwiązań usprawniających opiekę nad najmłodszymi - w co również wpisują się sysułka, sustentaculum i nocnik. Niezbyt bogaty ikonograficznie dział dotyczący karmienia niemowlęcia zdaje się potwierdzać ustalenia historyków na temat żywienia. Umieszczenie na obrazie kobiety karmiącej piersią (która nie jest Marią), dodatkowo w tak swobodnej sytuacji, pozwala sądzić nie tylko o ówczesnej akceptacji, ale i o promowaniu takiego sposobu żywienia najmłodszych dzieci. Naturalnością w zachowaniu charakteryzują się również dzieci przedstawione podczas zabawy - jakby podejrzane przez artystów, mimochodem przemycone przy zwykłych, codziennych czynnościach wykonywanych przez dorosłych. Prezentowane obrazy w połączeniu z ustaleniami historyków czy archeologów dają spójny, choć niepełny obraz codziennego funkcjonowania dziecka przed pięcioma wiekami.

${ }^{44}$ Zofia Ameisenowa opisuje to jako „coś nieprzyzwoitego” co zrobiło dziecko. Taką sytuację może sugerować fakt, iż chłopiec nie ma na sobie pieluszki. Porównanie natomiast wizerunku tego obiektu z przerysami archeologicznymi pozwoliło mi sądzić, iż jest to drewniany bąk (Por. Z. Ameisenowa, Kodeks Baltazara Behema, Warszawa 1961, s. 40). 


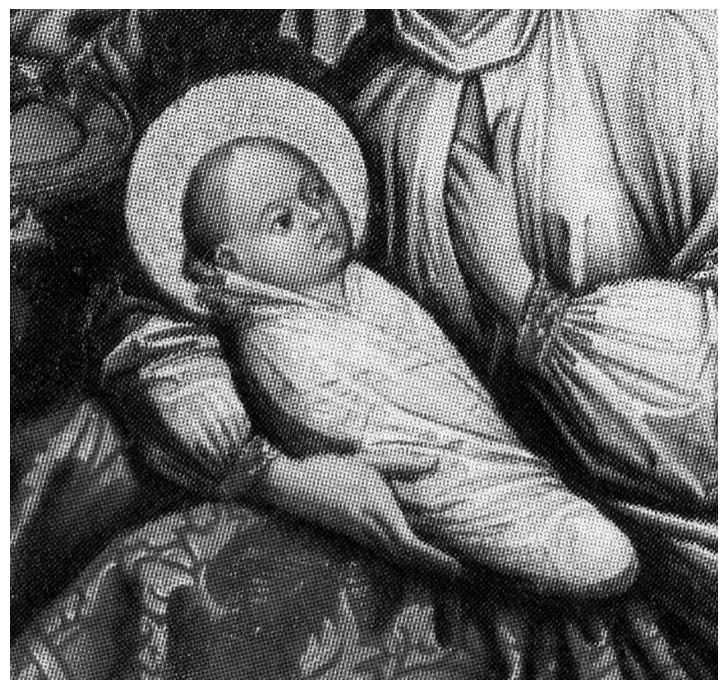

1. Powijaki bez okrycia glowy: fragm. kwatery Narodziny Marii, Jan Wielki, Stanisław Stary, Poliptyk olkuski, ok. 1485 r., kościół pw. św. Andrzeja, Olkusz. Źródło: J. Gadomski, Jan Wielki. Krakowski malarz z drugiej połowy wieku XV, Kraków 2005, il. 12.

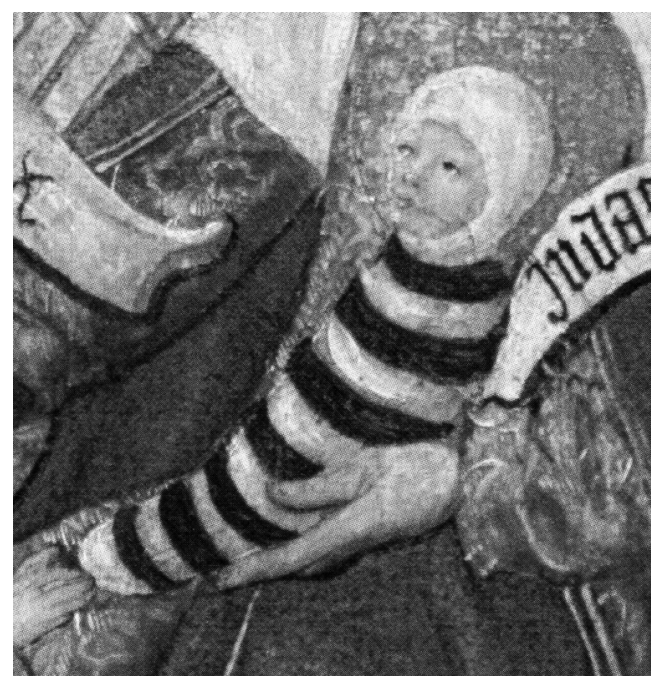

2. Powijaki z okryciem głowy: fragm. obrazu Wielka Święta Rodzina, ok. 1510-1515, kościół pw. św. Zygmunta, Szydłowiec. Źródło: D. Żołądź-Strzelczyk, K. Kabacińska-Łuczak, Codzienność dziecięca opisana stowem i obrazem. Życie dziecka na ziemiach polskich od XVI do XVIII w., Warszawa 2012, il. 44. 


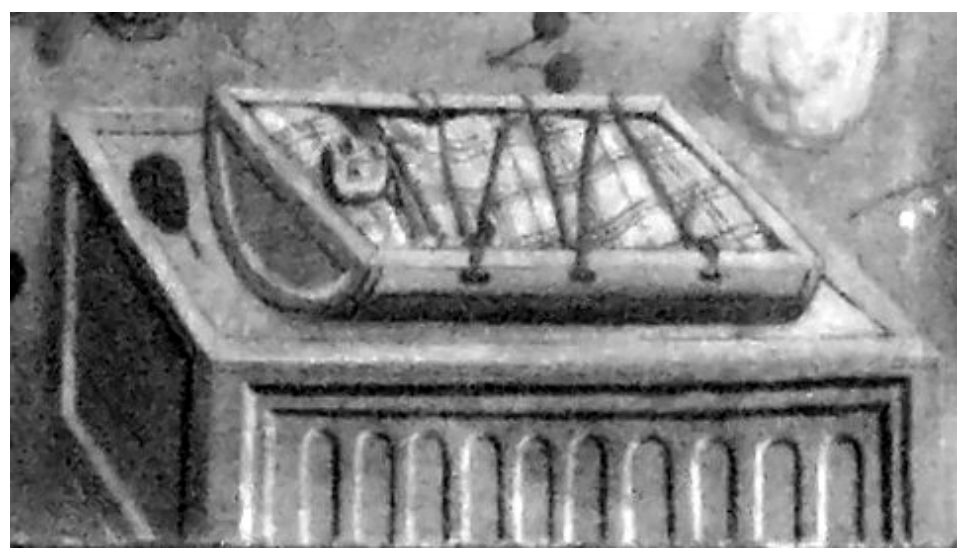

3. Kołyska: fragm. tryptyku Rodzina Marii, 1519 r., kościół pw. św. Rocha, Stobiecko Miejskie, 2014 r. Fot. M. Gudowska.

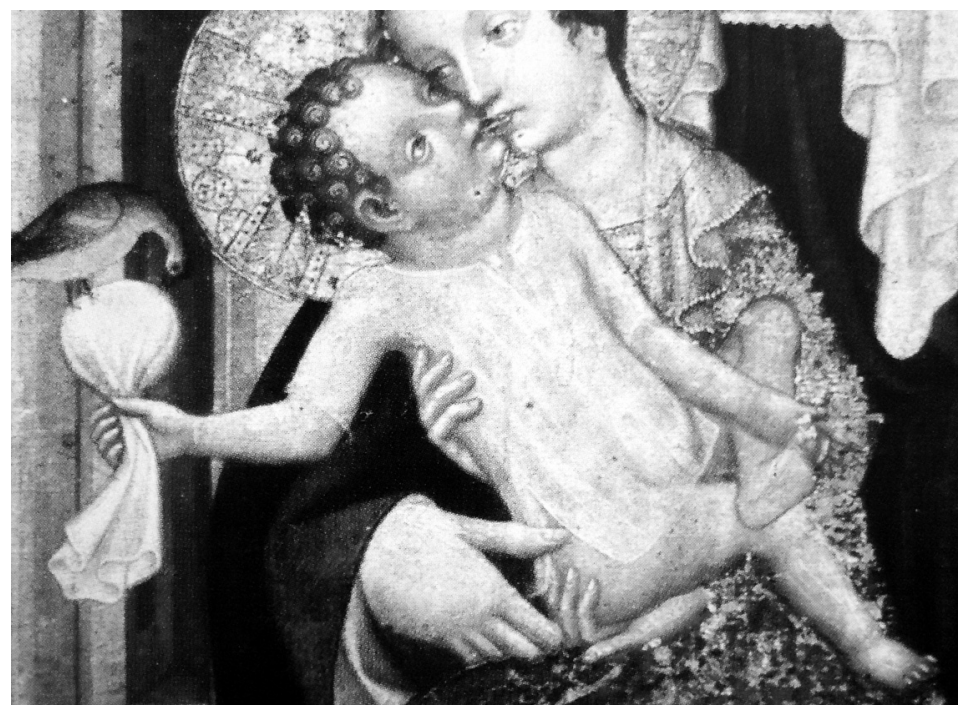

4. Sysułka: fragm. obrazu Św. Anna Samotrzeć, ok. 1400 r., kościół karmelitów, Strzegom. Źródło: Malarstwo gotyckie w Polsce, red. A.S. Labuda, K. Secomska, Warszawa 2004, il. XCIV. 


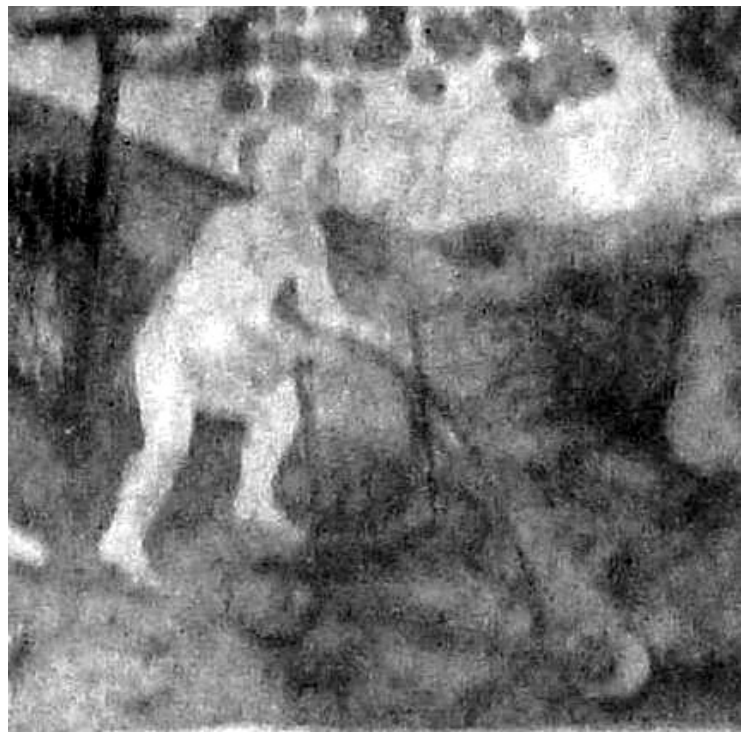

5. Sustentaculum: Niewiniątka $w$ raju, pocz. XVI w., fragm. malowidła z krużganków, kościół augustianów, Kraków, 2014 r. Fot: A. Koprowska.

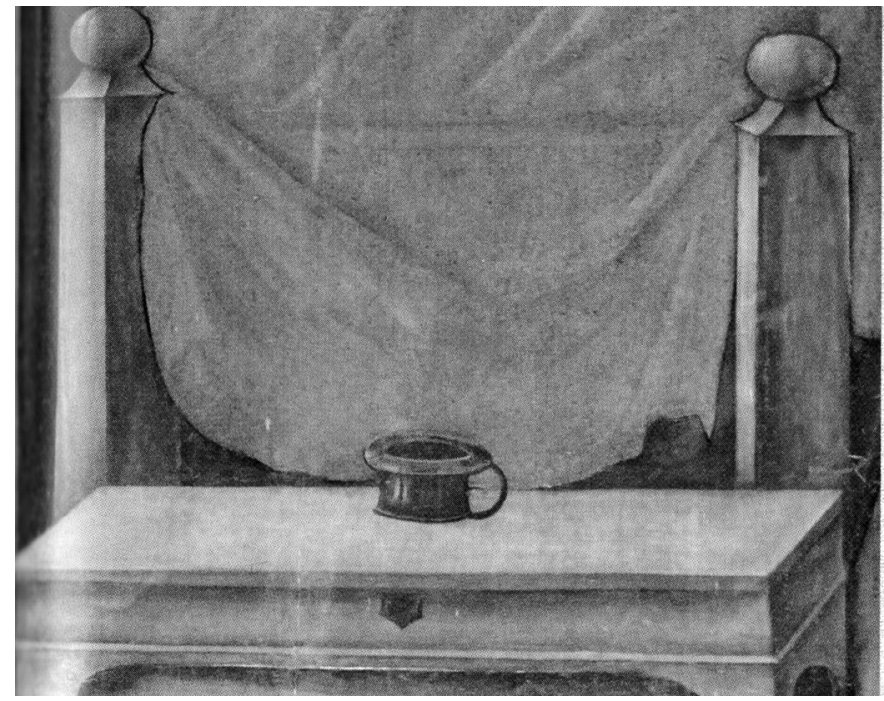

6. Nocnik: fragm. obrazu Św. Mikołaj obdarowujacy trzy ubogie dziewczęta, 1510-1520, kościół pw. św. Zygmunta, Żelichów. Żródło: D. Żołądź-Strzelczyk, K. Kabacińska-Łuczak, Codzienność dziecięca opisana słowem i obrazem. Życie dziecka na ziemiach polskich od XVI do XVIII w., Warszawa 2012, il. 128 . 


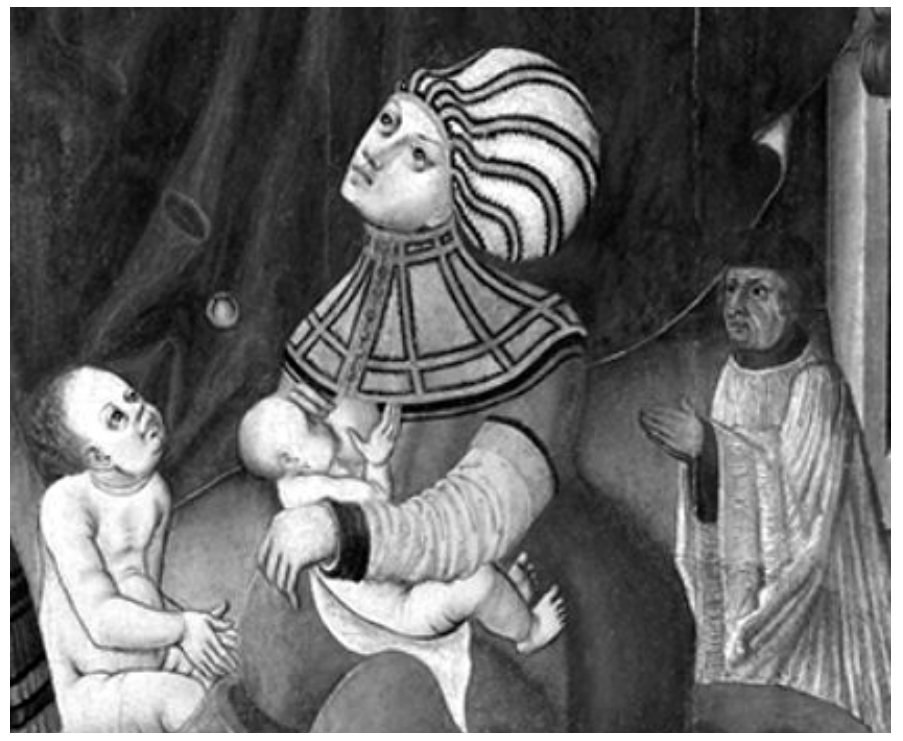

7. Karmienie piersią: fragm. tryptyku Rodzina Marii, ok. 1530-1540, kościół pw. Narodzenia NMP, Racławice Olkuskie, obecnie Muzeum Archidiecezjalne im. Kardynała Karola Wojtyły w Krakowie. Źródło: http://muzea.malopolska.pl/ obiekty/-/a/54355/1126787 (dostęp: 10.10.2016).

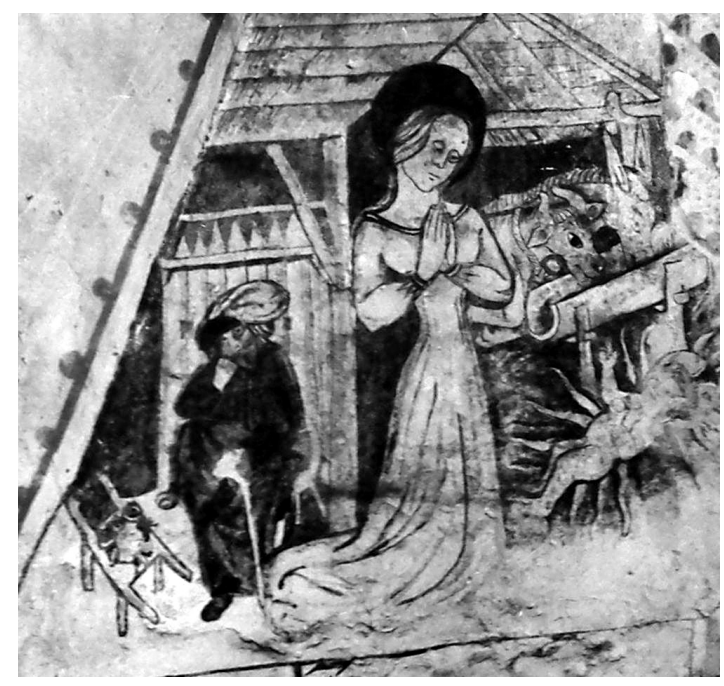

8. Przygotowywanie posiłku: fragm. malowidła Adoracja Dzieciątka, 2. poł. XV w., prezbiterium, ściana południowa, przęsło wschodnie, kościół pw. Serca Pana Jezusa, Pogorzela. Źródło: Malarstwo gotyckie w Polsce, red. A.S. Labuda, K. Secomska, Warszawa 2004, il. 52. 


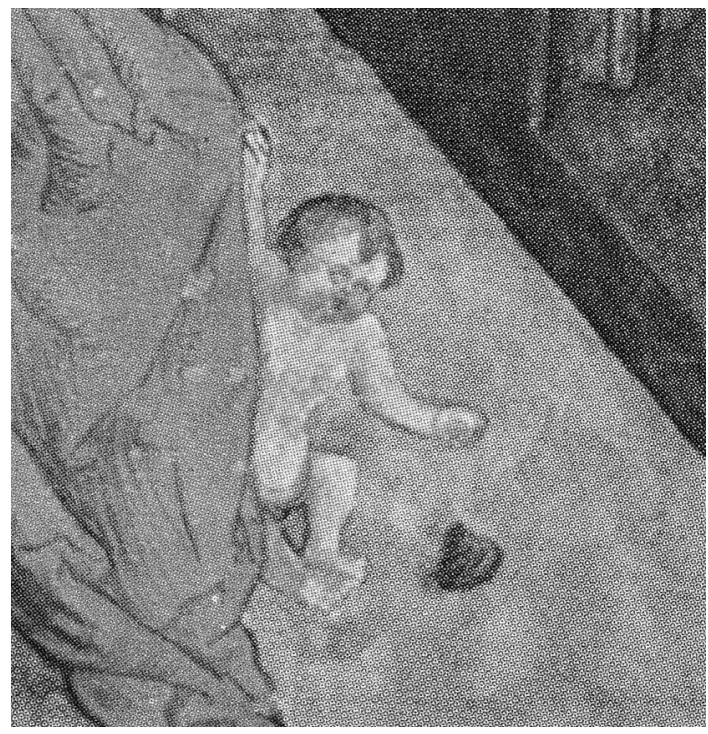

9. Zabawa bączkiem: fragm. miniatury Warsztat szewski, Baltazar Behem, Kodeks, ok. 1505 r., k. 287, Biblioteka Jagiellońska, Kraków. Źródło: Z. Ameisenowa, Kodeks Baltazara Behema, Warszawa 1961, il. 111.

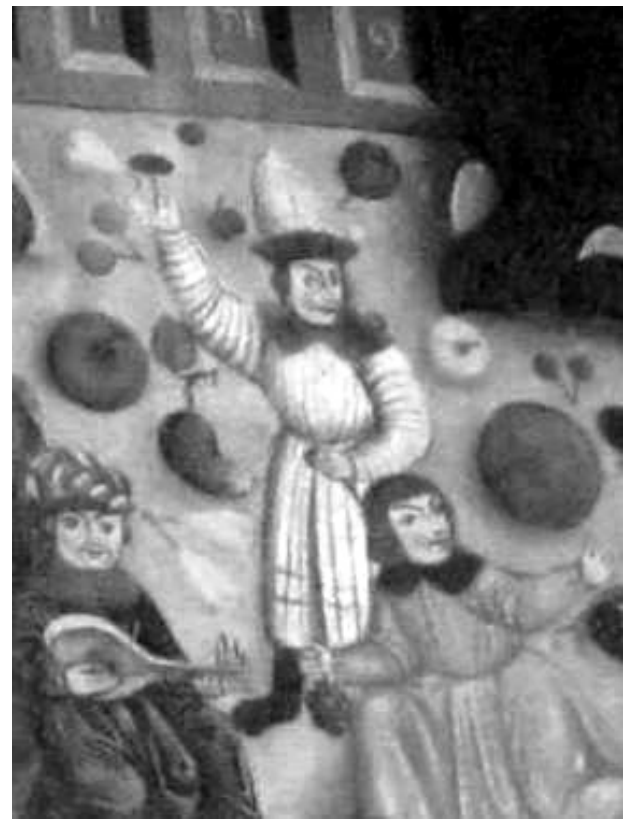

10. Zabawa bączkiem: fragm. tryptyku Rodzina Marii, 1519 r., kościół pw. św. Rocha, Stobiecko Miejskie, 2014 r. Fot. M. Gudowska. 


\section{BIBLIOGRAFIA}

Borkowski Tomasz, Gry i zabawy w średniowiecznym mieście na Śląsku. Ślady materialne, w: Kultura średniowiecznego Śląska i Czech, red. K. Wachowski. Wrocław 1995, s. 99-105.

Brückner Aleksander, Dzieje kultury polskiej, t. 1: Od czasów prehistorycznych do r. 1506, Kraków 1930.

Danysz Antoni, $O$ wychowaniu królewicza traktat humanistyczno-pedagogiczny z roku 1502, „Prace monograficzne z dziejów wychowania i szkolnictwa w Polsce”, Nr 3: Studia z dziejów wychowania w Polsce, Kraków 1921, s. 1-28.

Delimata Małgorzata, Dziecko w Polsce średniowiecznej, Poznań 2004.

Dobrowolski Witold, Jesus with a sustentaculum, w: Ars auro prior. Studia Ioanni Biatostocki sexagenario dicata, red. J.A. Chrościcki i in., Warszawa 1981, s. 201-208.

Drabina Jan, Życie codzienne w miastach ślaskich XIV i XV w., Wrocław 1998.

Ginekologia Soranusa z Efezu, tłum. J. Lachs, „Roczniki Towarzystwa Przyjaciół Nauk Poznańskiego", 28 (1902) s. 1-112.

Jelicz Antonina, Życie codzienne w średniowiecznym Krakowie (wiek XII-XV), Warszawa 1966.

Kliś Zdzisław, Temat Bożego Narodzenia w polskiej sztuce średniowiecznej, Kraków 1994.

Legenda świętej Jadwigi, thum. A. Jochelson, Wrocław 1993.

Lewiński Stefan, Niektóre zagadnienia dotyczace higieny we wczesnośredniowiecznych osiedlach na terenie Polski, „Acta Universitatis Nicolai Copernici. Nauki Humanistyczno-Społeczne. Archeologia IV", 60 (1974) s. 139-149.

Marcinkowski Mirosław, Zabawki dzieci elblaskich. Prezentacja zbioru z badań wykopaliskowych, w: Dawne i współczesne zabawki dziecięce, red. D. Żołądź-Strzelczyk, K. Kabacińsk, Poznań 2010, s. 55-67.

Teterycz-Puzio Agnieszka, Dziecko $i$ dzieciństwo $w$ świetle wybranych źródel narracyjnych (do XIV w.), „Studia Gdańskie”, 28 (2011) s. 257-276.

Tyszkiewicz Jan, Ludzie i przyroda w Polsce średniowiecznej, Warszawa 1983.

Silska Sylwia, Ewolucja pogląów na żywienie niemowląt $w$ XIX $i$ XX wieku, Poznań 2013, mps, Archiwum Uniwersytetu Medycznego im. Karola Marcinkowskiego w Poznaniu.

Stewart Amy, Zbrodnie roślin. Chwast, który zabit matkę Abrahama Lincolna i inne botaniczne okropieństwa, tłum. D. Wójtowicz, Warszawa 2012.

Wojciechowska Beata, Dziecko w kulturze Polski średniowiecznej, „Kieleckie Studia Historyczne", 9 (1991) s. 5-21.

Żołądź-Strzelczyk Dorota, Kabacińska-Łuczak Katarzyna, Codzienność dziecięca opisana stowem i obrazem. Życie dziecka na ziemiach polskich od XVI do XVIII wieku, Warszawa 2012.

Żołądź-Strzelczyk Dorota, Rozumienie dzieciństwa, w: Dziecko w rodzinie i społeczeństwie. Starożytność-średniowiecze, red. J. Jundziłł, D. Żołądź-Strzelczyk, t. 1, Bydgoszcz 2011, s. 9-24. 


\title{
CODZIENNOŚĆ NAJMLODSZYCH DZIECI W POLSKIM MALARSTWIE RELIGIJNYM 1400-1550
}

\begin{abstract}
Streszczenie
Artykuł prezentuje środowisko, w jakim funkcjonowały dzieci od narodzenia do ok. 4 roku życia na wybranych przykładach rodzimego malarstwa: tablicowego, ściennego i iluminatorstwa. Teskt został podzielony na trzy części: Powijaki. Kołyski. Akcesoria, Karmienie niemowlęcia oraz Zabawki. Pierwsza omawia najpotrzebniejsze rzeczy do opieki nad noworodkiem i niemowlęciem. W tej kategorii znalazły się oprócz wspominanych powijaków i kołysek również sysułka, sustentaculum oraz nocnik. Druga część analizuje sposoby żywienia: karmienie piersią oraz żywienie sztuczne. Ostatnia, poparta odkryciami archeologicznymi, skupia się na wyszczególnieniu zabawek. Dzięki źródłom ikonograficznym oraz ustaleniom historyków i archeologów tworzy spójną opowieść o funkcjonowaniu najmłodszych w późnym średniowieczu i u progu nowożytności.
\end{abstract}

Słowa kluczowe: obrazy religijne; dzieci; średniowiecze; zabawki dziecięce; życie codzienne

\section{EVERYDAY LIFE OF CHILDREN IN POLISH RELIGIOUS PAINTING 1400-1550}

\begin{abstract}
Summary
The article presents the environment in which children lived from their birth to about the age of four, illustrated with the selected examples of the native painting: panel painting, wall painting and illumination. The text is divided into three parts: Swaddling bands. Cradles. Accessories, Feeding infants and Toys. The first one discusses things necessary for looking after a newborn baby and an infant. This category includes, apart from swaddling bands and cradles mentioned above, tied-cloth 'pacifiers', sustentaculum and chamber pots. The second part analyses different methods of feeding such as breastfeeding and formula feeding. The last section, based on archeological discoveries, focuses on toys. Thanks to iconographic sources and findings presented by historians and archeologists, the author was able to present a coherent story about the life of the youngest in the late Middle Ages and at the dawn of the early modern period.
\end{abstract}

Keywords: religious paintings; children; the Middle Ages; children's toys; everyday life 